\title{
Efficiency of Nano-formulations of Neem and Peppermint Oils on the Bionomics and Enzymatic Activities of Agrotis ipsilon Larvae (Lepidoptera: Noctuidae)
}

\author{
Abdel Rahman Hussein Amin ${ }^{1}$, Alaa El Din Bayoumi ${ }^{1}$, Nadia Zikry Dimetry ${ }^{2}$, \\ Dalia Abdellah Youssef ${ }^{2}$ \\ ${ }^{1}$ Department of Plant Protection, Faculty of Agriculture, Ain Shams University, Cairo, Egypt \\ ${ }^{2}$ Department of Pests and Plant Protection, National Research Centre, Dokki, Cairo, Egypt
}

Email address:

nadia_dimetry@yahoo.com (N. Z. Dimetry)

\section{To cite this article:}

Abdel Rahman Hussein Amin, Alaa El Din Bayoumi, Nadia Zikry Dimetry, Dalia Abdellah Youssef. Efficiency of Nano-formulations of Neem and Peppermint Oils on the Bionomics and Enzymatic Activities of Agrotis ipsilon Larvae (Lepidoptera: Noctuidae). International Journal of Natural Resource Ecology and Management. Vol. 4, No. 5, 2019, pp. 102-111. doi: 10.11648/j.ijnrem.20190405.11

Received: June 24, 2019; Accepted: July 19, 2019; Published: August 12, 2019

\begin{abstract}
Nanotechnology is considered to be a development way to gain efficient and potential approaches towards pest control. The effect of both neem and peppermint oils as bulk, nano and loaded nano-emulsions have been studied against the different biological aspects of the $2^{\text {nd }}$ larval instar of Agrotis ipsilon (Hufn.) under laboratory conditions. Their effects on enzymatic activities were investigated for the $2^{\text {nd }}$ and $4^{\text {th }}$ larval instars. The effects of adding the different formulations of either neem or peppermint oils to artificial diet of $2^{\text {nd }}$ instar larvae show significant elongation of the larval duration; percentage mortalities were increased as well as larval malformations. It was recorded that nano-formulations (emulsion or loaded) significantly decreased the pupal weight and significantly increased the pupal duration, percentage pupal mortalities and pupal malformation. Adult longevity show insignificant effect, while female fecundity and percentage egg fertility show significant decrease in comparison with the control. Results of enzymatic activities show marked effects of the three formulations of either neem or peppermint oil. Significant inhibitions were recorded for amylase, invertase, trehalase, protease and alkaline phosphatase. However, significant increase in the activities of cuticle phenoloxidase and chitinase were recorded. Marked variations were recorded between nano-formulations and the bulk form.
\end{abstract}

Keywords: Neem Oil, Peppermint Oil, Nano-formulations, BIONOMICS, Enzymes, Agrotis ipsilon

\section{Introduction}

Larvae of Agrotis ipsilon are feeding above ground until about the fourth instar. Larvae can consume over $400 \mathrm{sq} \mathrm{cm}$ of foliage during their development, but over $80 \%$ occurs during the terminal instar, and about $10 \%$ in the instar immediately preceding the last. Thus, little foliage loss occurs during the early stages of development. Once the fourth instar is attained, larvae can do considerable damage by severing young plants, and a larva may cut several plants in a single night [1]. Cutworm is nocturnal as it attacks the young seedling of the plants at night. Larvae can damage many cultivated and wild plant species as tobacco, potato, tomato, lettuce, cabbage, spinach, turnip, eggplant, broccoli and many ornamental plants [2]. The larva feeds on the plants by cutting their stem either below or just above the ground level, hide and live inside the cracks and holes in the soil during the day $[3,4]$.

Based on such facts of damages caused by such insect pest, several methods and techniques were and still followed using conventional chemical and/or synthetic insecticides. These insecticides caused various levels of hazards both on human, animal health as well as the environmental components.

In order to reduce the effects of conventional synthetic pesticides, botanical insecticides are increasingly attracting research attention as they offer novel modes of action that may provide effective control of pests that have already developed resistance to conventional insecticides. Biopesticides based on plant extracts and/or essential oils 
(EOs) appear to be a complementary or alternative method in crop production and integrated pest management. They potentially offer cost-effective pest control to small farmers in developing countries if highly active extracts can be prepared simply from readily available plants [5].

Extracts from the neem tree "Azadirachta indica A. Juss" and essential oils of other plant origins are active against hundreds of pest species of several insect orders and mites having limited effects on non-target species, including vertebrates and beneficial insects. They are used as alternatives to the traditional chemical pesticides which lead to environmental imbalance according to their harmful effect on natural enemies, or the occurrence of pest resistance and the harmful effect of pesticides residues in soil or plant. So that, it is important to find safe alternatives like plant extracts or essential oils which have shown successful results in pest control, as they have insecticidal activity, affect the pest fecundity, provide antifeedant and/or deterrent effect as well as affect the biochemical processes inside the insect body. From another point of view, one of the disadvantages of the traditional botanical products is their limited stability when applied in the field. Based on the facts referred to the huge number of botanical extracts, it was found that neem extract (derived from the tree Azadirachta indica) and peppermint (Mentha pipreta) are the most active plant extracts among others. Their insecticidal activity is based on their mode of action as interfering with larval growth and development, growth retardation, molting inhibition, or induction of malformation in the larval stage. In the adult insect, these extracts inhibit egg maturation and may also induce sterilization in several insect species and such effects can also be induced as hormone application [6, 7].

To overcome the disadvantages of the traditional botanical extracts, i.e. instability, chemical decomposition and hence loss their insecticide properties, green nano-technology is a successful way which is recently used to improve the pesticidal properties of botanical insecticides. Nanotechnology has grown to be an important research field in all areas. The size, orientation and physical properties of nanoparticles have reportedly shown to change the performance of any material [8]. Development of green processes for the synthesis of nano-particles is evolving into an important branch of nanotechnology [9]. However, phytochemicals such as secondary metabolites and essential oils face problems of stability and cost effectiveness. In case of essential oils, their chemical instability in the presence of air, light, moisture, and high temperatures that cause rapid evaporation and degradation of some active components are major concern. Incorporation of essential oils into a controlled-release nano-formulation prevents rapid evaporation and degradation; enhances stability and maintains the minimum effective dosage/application due to coating process [10].

Furthermore, this kind of formulation is expected to be more effective than the bulk substances [11-13]. On the other hand, it has been found that pesticide nano formulation showed less toxicity towards non target organisms compared with bulk or commercial formulations and therefore a higher specificity was observed [14].

The objective of the present investigation is to study the role of nano and loaded nano-formulations of neem and pepper mint oil in comparison to bulk form of these oils against the different biological parameters of $A$. ipsilon larvae. Also, the effect of the prepared nano-formulations on some biochemical parameters in A. ipsilon larvae was carried out.

\section{Materials and Methods}

\subsection{Test Insect}

Agrotis ipsilon (Hufn.) was maintained for several generations in rearing units in the Department of Pests and Plant protection (National Research Center) under controlled conditions of $25 \pm 2^{\circ} \mathrm{C}$. and $65 \pm 5 \%$ R.H. For adult stage, the moths were reared in glass jars measuring $15 \times 25 \mathrm{~cm}$. Females laid their egg masses on black muslins. A sucrose solution of $10 \%$ concentration was provided for feeding the moths. Newly laid egg masses were collected. The old tissue paper replaced by new one and theadults were provided with fresh feeding solution. Newly hatched larvae were gently transferred into plastic jars containing a suitable amount of clean castor leaves. When larvae reached their $3^{\text {rd }}$ instars, they were separated singly in several plastic boxes to prevent cannibalism between the larvae. The resulting pupae were collected from the larval containers to other containers provided with wooden sawdust.

\subsection{Tested Plant Extract and Essential Oil}

Two substances were tested in this work, i.e.neem oil extract $(0.03 \%$ azadirachtin), derived from (Azadirachta indica) was kindly obtained from Dr. Kleeberg, Lahnaw, Germany. Pepper mint oil, (the mentol content was 26\%) as an essential oil derived from (Mentha pipreta) was obtained from oil extraction unit, National Research Centre, Cairo, Egypt. The mentioned essential oil was extracted from peppermint according to the method described by Guenther, E. et al. $[15,16]$.

\subsection{Preparation of Nano-formulations}

\subsubsection{Nano-emulsion Preparation}

Nano-emulsion preparations were prepared by diluting the neemoil with distilled water in ratio of $1: 1$ (oil to water, respectively) in case of neem oil, while in ratio of 1:2 (oil: water, respectively) in case of pepper mint oil. Two percent of Tween 80 was added as an emulsifier. The formed emulsion was sonicated during $30 \mathrm{~min}$ using ultrasonic cleaner set, model WUC-DO3H $290 \mathrm{~W}$ and $60 \mathrm{~Hz}$, then sonicated for $1 \mathrm{~min}$ using a high energy ultra sonication probe model VCX750, $750 \mathrm{~W}, 20 \mathrm{kHz}$, and resonicated $30 \mathrm{~min}$ by the ultrasonic cleaner under cooling conditions using ice path according to Yousef, Dalia A. et al. [17].

In another experiment neem oil was sonicated using ultrasonic cleaner set, only for I hour without using high 
energy ultra sonication probe.

\subsubsection{Preparation of Loaded Nano-emulsions}

Sodium alginate solution $(3 \%, \mathrm{w} / \mathrm{v})$ was prepared by dissolution in distilled water at $50^{\circ} \mathrm{C}$ for 45 min. Tested oils were diluted by distilled water using Tween 80 as an emulsifier with mechanical stirring for $10 \mathrm{~min}$. The emulsion thus formed were sonicated for $30 \mathrm{~min}$ using ultrasonic cleaner set, and then sonicated for 2 min using a high energy ultra sonication probe. An appropriate volume of $\mathrm{CaCl}_{2}(2: 10$ $\mathrm{CaCl}_{2}$ to alginate, respectively) was then added into the resulting emulsion and stirred for an additional $30 \mathrm{~min}$ and sonicated as mentioned previews according to the method described by Lertsutthhiwong et al. [18]. The loaded nanocapsule suspension was equilibrated overnight. Nanocapsules were obtained as dispersion in aqueous solution.

In another experiment, pepper mint oil was tested with diluting by ethanol as a solvent instead of water and was removed after equilibration under reduced pressure at 40 $45^{\circ} \mathrm{C}$ for $20 \mathrm{~min}$.

\subsection{Effect of Nano-formulations of Neem and Pepper Mint Oil on Different Biological Aspects of A. ipsilon Second Instar Larvae}

The biological effects of prepared nano-compounds compared with their bulk form were studied on the $2^{\text {nd }}$ insar larvae of $A$. ipsilon. Emerged $2^{\text {nd }}$ instars larvae were treated with concentrations of $0.75 \mathrm{ppm}$ azadirachtin for neem oil and $10 \mathrm{ppm}$ menthol for pepper mint formulations. Forty larvae were used for each concentration and transferred separately in glass tubes. The larvae were exposed to the treated diet until pupation. Untreated diet was used as a control by adding distilled water mixed with $100 \mu \mathrm{l}$ of Tween 80. Records were made daily of living and dead individuals. The duration of larval and pupal stages with their malformations were recorded. The resulting Pupae were weighed on the first day after pupation. Fecundity was determined by rearing each couple of emerged moths and calculating the number of eggs deposited by each female and hatchability percentage of produced eggs were calculated.

\subsection{Effect of the Tested Nano and Bulk Formulation of Neem and Pepper Mint Oil on Certain Enzymatic Activity of A. ipsilon Larvae}

The biochemical effects of the prepared neem and pepper mint oils either in bulk and/or in nano-formulations (nanoemulsion and loaded nano-emulsion) were studied throughout the determination of certain enzymatic activities, i.e. $\alpha$-amylase, trehalase, invertase, protease, alkaline phosphatase, phenol oxidase and chitinase in both $2^{\text {nd }}$ and $4^{\text {th }}$ treated instar larvae of $A$. ipsilon. Both instars were treated by their corresponding calculated $\mathrm{LC}_{50}$ values of each formulation.

The treatment procedure was carried out by mixing the concentration of each $\mathrm{LC}_{50}$ value of each formulation by the semi-synthetic diet. After then, the $2^{\text {nd }}$ and/or $4^{\text {th }}$ instar larvae were allowed to feed the treated diet during 4 days. At the fourth day of treatment the live larvae of both tested instars were selected to perform the enzyme extraction procedure.

\subsubsection{Preparation of Enzyme Extracts}

Both $2^{\text {nd }}$ and $4^{\text {th }}$ instars larvae were homogenates in a volume of potassium phosphate buffer $(0.2 \mathrm{M}, \mathrm{pH} 7.0)$ equal to 4 times their weights. Individuals of $4^{\text {th }}$ instars larvae were dissected and gut canals were removed and collected for determination of $\alpha$-amylase, invertase, trehalase, protease and alkaline phosphatase enzyme activities. Cuticle samples were collected for the phenol oxidase and chitinase enzyme activities. The homogenates were centrifuged at 10,000 xg for $15 \mathrm{~min} / 4^{\circ} \mathrm{C}$ and the supernatant was used as the enzyme source.

\subsubsection{Determination of Carbohydrate Hydrolyzing Enzymes Activities}

The activities of three carbohydrate hydrolyzing enzymes were determined, i.e. $\alpha$-amylase (which hydrolyzing the starch), invertase (which hydrolyzing the sucrose) and trehalase (which hydrolyzing the trehalose). It was selected such three enzymes to reflex the effect of the studied bulk and nano-formulations on the physiological functions of the digestive system of the affected instar larvae.

The determination procedure of the three mentioned enzymes was carried out according to the method described by Ishaaya, I. et al. [19, 20]. Such method was based on the digestion of starch, and sucrose by $\alpha$-amylase, and invertase, respectively. The free aldhydic group of glucose formed after starch and/or sucrose digestion was determined using 3,5 dinitrosalicylic acid reagent. The enzymatic activity was expressed as $\mu$ g glucose released/ min./ mg protein.

\subsubsection{Determination of Protease Activity}

The proteolytic activity was determined by the casein digestion method described by Ishaaya et al. [21]. Enzymatic activity was expressed by measuring the resultant optical density at $280 \mathrm{~nm}$ and the O.D. multiplicities by $10^{3}$.

\subsubsection{Determination of Alkaline Phosphatase Activity}

Alkaline phosphatase (AlkP) activity was determined according to the method described by Powell, M. E. A. and M. J. H. Smith [22]. The produced colour was measured immediately by spectrophotometer at $510 \mathrm{~nm}$. The enzymatic activity is expressed as $\mu$ phenol released $/ \mathrm{min} . / \mathrm{mg}$ protein. The Quantification of enzyme activity was carried out through standard calibration curve used phenol as standard.

\subsubsection{Determination of Chitinase Activity}

Chitinase was assayed using 3,5-dinitrosalicylic acid reagent to determine the free aldehydic groups of hexoaminase liberated on chitin digestion according to the method described by Ishaaya, I. and J. E. Casida [23]. The specific activity of chitinase is expressed as $\mu \mathrm{g} \mathrm{N}$ acetylglucosamine released $/ \mathrm{min} / \mathrm{mg}$ protein.

\subsubsection{Determination of Phenol Oxidase Activity}

Phenol oxidase activity was determined according to a modification of the method described by Ishaaya et al. [21], 
in a reaction mixture consisting of $0.5 \mathrm{ml}$ sodium phosphate buffer (0.1 M, PH 7), $200 \mu \mathrm{l}$ enzyme solution and $200 \mu \mathrm{l}$ catechol solution $2 \%$. Prior to the initiation of the reaction, the substrate and other ingredients of the reaction mixture were separately incubated at the optimum temperature of the reaction $\left(25^{\circ} \mathrm{C}\right)$. Enzyme reaction was initiated by adding catechol solution. Then after exactly $1 \mathrm{~min}$, the optical density was determined. Zero adjustment was against sample blank. The specific activity was determined as O.D.units $\times$ $10^{3}$ at an absorbance of $405 \mathrm{~nm} / \mathrm{min} / \mathrm{mg}$ protein using UV spectrophotometer, CHEM-7.

\subsection{Determination of Total Proteins}

Total proteins were determined by the method of Bradford [24]. The resultant colour of protein -dye complex was read at $595 \mathrm{~nm}$ using UV spectrophotometer, CHEM-7.

\subsection{Statistical Analysis}

Data were subjected to statistical analysis by one way analysis of variance (ANOVA) using SPSS software (Tukey test). A value of $p<0.05$ was considered statistically significant. Percentage values were transformed to Arcsin before statistical analyses.

\section{Results and Discussion}

\subsection{Effects of Neem Oil Nano-formulations on Different Biological Aspects of A. ipsilon}

Data obtained in Table 1 show the effects of adding three formulations of neem oil (bulk, nano-emulsion and loaded nano-emulsion) at sublethal dose $(0.75 \mathrm{ppm}$ azadirachtin) to artificial diet which fed to $2^{\text {nd }}$ larval instar of A. ipsilon. Their effects on bionomics in comparison with control have been evaluated. Statistical analysis of these data showed significant difference between means of most items. The larval duration was prolonged in the three treatments than in control. Means of larval duration were 22.71, 24.40 and 24.28 days for bulk, nano-emulsion and loaded nanoemulsion, respectively compared with 18.82 days for the control.

The percentages of larval mortalities were increased in the three tested formulations in comparison with control $(5.00 \%)$, while the maximum percentage mortality $(82.50 \%)$ was occurred in larvae treated with nano-emulsion, followed by loaded nano-emulsion $(45.00 \%)$, while bulk oil produced $(10.00 \%)$. These results indicated that neem oil at all formulations caused different categories of larval mortalities according to its formulation. The larvae fed with three formulations of neem oil produced malformed larvae (Table 1).
Also, pupal duration was prolonged with regards to control treatment (10.08 days) while mean duration of the two treatments were 12.77 and13.13for bulk oil and nanoemulsion, respectively. A significant decrease was occurred in pupal weight in the three formulations in comparison with control (410.00 days) while means pupal weight for the three treatments were $384.62,359.17$ and $365.45 \mathrm{mg}$ for bulk oil, nano-emulsion and loaded nano-emulsion, respectively. Also, significant difference between mortality percentages of pupae was occurred in the three treatments. The highest mean percentage mortality was $100.00 \%$ for loaded nanoemulsion (Table 1). The percentage of pupal malformation showed significant difference between means. The highest percentage was $50.00 \%$ produced from loaded nanoemulsion, while control treatment produced $5.00 \%$ malformed pupae.

From the results obtained, it could be stated that adding neem oil to $2^{\text {nd }}$ instar larvae with different formulations caused prolongation in pupal duration, decrease in pupal weight, increasing in percentage of pupal mortality as well as increasing in percentage of pupal malformation. Rao et al. [25] showed that the $\mathrm{LC}_{50}$ values for neonate and the second instar larvae of $H$. armigera were $0.002 \%$ and $0.004 \%$ when fed Neem Azal-treated cotton leaves continuously. The $\mathrm{LC}_{50}$ values were $0.005 \%, 0.02 \%$, and $0.03 \%$ for the first, second, and third instar larvae of $H$. armigera, respectively when the exposure was limited to $48 \mathrm{hr}$. Furthermore, they reported that the concentration of $200 \mathrm{ppm}$ of Neem Azal significantly reduced larval and pupal weight in comparison with control.

The resulting adult longevity was insignificantly affected by the treatments, although means adult longevity were decreased than control. Fecundity of resulted adult females showed significant decreasing in the two formulations of neem oil in comparison with control treatment (916.67 eggs/female). The maximum decrease was occurred in nanoemulsion (588.33 eggs /female). Regarding egg hatchability, results showed significant difference between mean percentages of hatchability. The two formulations percentages of hatchability were $21.00 \%$ and $72.00 \%$ for nano-emulsion and bulk neem oil respectively. Ma et al. [26] studied the toxicity and biological effects of azadirachtin on first and second instar larvae of $H$. armigera. High mortality of larvae, growth retardation, including reduced larval and pupal weight, and extension of development were observed in the treatment. Similar effects were observed in the present study.

From the aforementioned results it could be stated that $2^{\text {nd }}$ instar larvae fed on neem nano-emulsions produced females that gave the least mean numbers of eggs.

Table 1. Effects of neem oil nano-formulations on certain biological aspects of the $2^{\text {nd }}$ instar larvae of A. ipsilon.

\begin{tabular}{|c|c|c|c|c|c|}
\hline $\begin{array}{ll}\text { Parameter } & \text { Formulation } \\
\end{array}$ & Bulk oil & Nano-emulsion & $\begin{array}{l}\text { Loaded nano- } \\
\text { emulsion }\end{array}$ & Control & Mean/F \\
\hline Larval duration (days) & $22.71 \pm 0.51^{b}$ & $24.40 \pm 0.34^{\mathrm{a}}$ & $24.28 \pm 0.82^{\mathrm{a}, \mathrm{b}}$ & $18.82 \pm 0.10^{\mathrm{c}}$ & $39.80 * *$ \\
\hline \%Larval mort. (*) & $\begin{array}{l}10.00 \\
18.43 \pm 0.55^{\mathrm{c}}\end{array}$ & $\begin{array}{l}82.50 \\
21.13 \pm 0.49^{b}\end{array}$ & $\begin{array}{l}45.00 \\
42.10 \pm 0.35^{\mathrm{a}}\end{array}$ & $\begin{array}{l}5.00 \\
12.87 \pm 0.78^{d}\end{array}$ & $514.68 * *$ \\
\hline$\%$ Malformations in larvae $(*)$ & 10.00 & 19.07 & 9.82 & 4.30 & $268.28 * *$ \\
\hline
\end{tabular}




\begin{tabular}{|c|c|c|c|c|c|}
\hline $\begin{array}{ll}\text { Parameter } & \text { Formulation } \\
\end{array}$ & Bulk oil & Nano-emulsion & $\begin{array}{l}\text { Loaded nano- } \\
\text { emulsion }\end{array}$ & Control & Mean/F \\
\hline & $18.40 \pm 0.49^{\mathrm{c}}$ & $25.83 \pm 0.43^{b}$ & $33.20 \pm 0.35^{\mathrm{a}}$ & $11.47 \pm 0.84^{\mathrm{d}}$ & \\
\hline Pupal duration (Days) & $12.77 \pm 0.23^{\mathrm{a}}$ & $13.13 \pm 0.22^{\mathrm{a}}$ & - & $10.08 \pm 0.26^{\mathrm{b}}$ & $48.48 * *$ \\
\hline Pupalwt/mg & $384.62 \pm 7.13^{\mathrm{a}, \mathrm{b}}$ & $359.17 \pm 8.55^{\mathrm{b}}$ & $365.45 \pm 14.48^{\mathrm{b}}$ & $410.00 \pm 11.43^{\mathrm{a}}$ & $4.20^{*}$ \\
\hline \% Pupal mortality (*) & $\begin{array}{l}20.00 \\
26.57 \pm 0.43^{\mathrm{c}}\end{array}$ & $\begin{array}{l}27.27 \\
31.33 \pm 0.38^{\mathrm{b}}\end{array}$ & $\begin{array}{l}100 \\
90.00 \pm 0.00^{\mathrm{a}}\end{array}$ & $\begin{array}{l}7.00 \\
15.30 \pm 0.64^{\mathrm{d}}\end{array}$ & $612.4 * *$ \\
\hline$\%$ Malformations in pupa $(*)$ & $\begin{array}{l}20 \\
26.57 \pm 0.43^{\mathrm{c}}\end{array}$ & $\begin{array}{l}30 \\
33.20 \pm 0.35^{\mathrm{b}}\end{array}$ & $\begin{array}{l}50 \\
45.00 \pm 0.35^{\mathrm{a}}\end{array}$ & $\begin{array}{l}5 \\
\left(12.87 \pm 0.78^{\mathrm{d}}\right)\end{array}$ & $694.22 * *$ \\
\hline Adult longevity (days) & $6.67 \pm 0.34^{\mathrm{a}}$ & $6.33 \pm 0.33^{\mathrm{a}}$ & - & $7.67 \pm 0.33^{\mathrm{a}}$ & $4.33^{\mathrm{NS}}$ \\
\hline Fecundity & $675.33 \pm 13.87^{\mathrm{b}}$ & $588.33 \pm 24.55^{\mathrm{b}}$ & - & $916.67 \pm 86.43^{\mathrm{a}}$ & $10.50^{*}$ \\
\hline$\%$ Hatchability $(*)$ & $72.00\left(57.52 \pm 1.63^{b}\right)$ & $21.00\left(26.57 \pm 0.43^{\mathrm{c}}\right)$ & - & $98.00\left(82.07 \pm 1.24^{\mathrm{a}}\right)$ & $529.23 * *$ \\
\hline
\end{tabular}

$(*)$ Arcsin transformation of percentage. NS= Not significant. * Significant. **Highly significant. Each value represent the means of four replicates (each composed of 10 larvae) \pm s.e.. Values with different letters within the same row are significantly different $(\mathrm{P} .<0.05)$ (ANOVA) (Tukey test).

\subsection{Effects of Peppermint Oil Nano-formulations on Different Biological Aspects of A. ipsilon}

Data obtained in Table 2 show the effects of adding three formulations of mint oil (bulk, nano-emulsion and loaded nano-emulsion) at sublethal dose (10 ppm menthol) to artificial diet which fed to $2^{\text {nd }}$ larval instar of $A$. ipsilon. Their effects on bionomics in comparison with control have been evaluated. Statistical analysis of these data show significant difference between means of most items. The larval duration was prolonged in the three treatments than in control (18.84 days). Means of larval duration were 30.41, 31.55 and 50.00 days for bulk, nano-emulsion and loaded nano-emulsion, respectively. These results indicated that mint oil in all formulations may inhibit digestive enzymes and caused retardation of larval duration. These phenomena are in harmony with our findings in enzymatic activities. These results show that all digestive enzymes were inhibited when $2^{\text {nd }}$ instar larvae treated with the three formulations of mint oil. The percentages of larval mortalities were increased in the three tested formulations in comparison with control $(5.00 \%)$. These results indicated that mint oil at all formulations caused different categories of larval mortality. Maximum mortality $(50 \%)$ was occurred in larvae treated with loaded nano-emulsion, followed by nano-emulsion while bulk oil produced the least percentage of larval mortalities $(17.50 \%)$. Treatment of peppermint formulations produced maximum malformed larvae in the percentages of $18.00 \%$ for loaded nano-emulsion.

Also, pupal duration was prolonged with regards to control treatment (Table 2). A significant decrease was occurred in pupal weight in the three formulations in comparison with control (410.00 days) while means pupal weight for the three treatments were $268.57,273.57$ and 250.00 for bulk oil, nano-emulsion and loaded nanoemulsion, respectively. Also, significant percentage mortality between resulting pupae was occurred in three treatments. The highest mean percentage mortality was $100.00 \%$ for loaded nano-emulsion. The percentage of pupal malformation showed significant difference between means. The highest percentage was $34.93 \%$ produced from loaded nano-emulsion, followed by nano-emulsion, while control treatment produced $2.50 \%$ malformed pupae.

From the aforementioned results, it could be stated that adding mint oil to $2^{\text {nd }}$ instar larvae with different formulations caused prolongation in pupal duration, decrease in pupal weight, increasing in percentage of pupal mortality as well as increasing in percentage of pupal malformation.

Adult longevity of the resulting adult was significantly affected by the two treatments, means adult longevity were decreased than control (7.50 days). Means of treatments were 6.20 and 5.00 days for bulk oil and nano-emulsion, respectively. Fecundity of resulted adult females showed significant decreasing in the two formulations of mint oil in comparison with control treatment (1081.60 eggs/female). The maximum decrease was occurred in nano-emulsion (488.75 eggs /female), followed by bulk oil (595.75 eggs/female). The obtained results show significant difference between mean percentages of egg hatchability.

A large number of plant secondary metabolites are known to affect insect growth, development and reproduction; their exact mechanisms of action remain to be established. The regulatory activities of our formulations also suggest the possibility of a future exploitation of these materials into potential insect management chemicals with a minimum environmental impact and crop protectant against $A$. ipsilon larvae.

The present findings clearly indicated that the tested plant extracts showed insecticidal properties and negatively affected the oviposition and reproductive parameters of $A$. ipsilon adults, affected the formation of pupal and adult stages. Generally these results suggested that the chemical structures of the tested plant extracts play an important role in the activity of these extracts as toxic substances against the adult stage of black cutworm. Also, these results are in agreement with Pineda, S. et al. [27] who suggested the changes in the population dynamics of the tested pests in treated crops. Mohamed [28] investigated the biological efficacy of two selected essential oils (geranium and garlic) in the form of nano-particles against the $3^{\text {rd }}$ larval instar of $S$. littoralis and A. ipsilon. It was reported that geranium and garlic essential oils free and loaded- solid lipid nano-particles at the concentrations $1.25 \%, 2.5 \%$ and $5 \%$ respectively significantly affected the developmental process of immature stages as well as increased the percentage of mortality at all treatments, but the higher percentage of larval and pupal mortality occurred when the larvae treated with geranium and garlic oils loaded -SLNs, than the bulk form. The 
biological effects of the botanical oils on insect pests may attribute to their effect on the insect neuro endocrine system and juvenile hormone leading to hormone unbalance occurring malformation and decreasing moths fecundity and egg fertility resembling the effect of the growth regulators as concluded by Sharaby, A. and A. El-Nojiban [29]. Huang et al. [30] attributed decreasing of fecundity and fertility to decreasing in periods and time of adults mating which lead to decreasing of ovulation, essential oils have neuro toxic, citotoxic and mutagenic actions among other different insects as investigated by Isman, M.B.; S. Miresmailli and C.
Machial [31]. The essential oils act at multiple levels in the insect, so the possibility of generating resistance is little probable [32]. The essential oils can affect chitin synthesis and inhibit the process of ecdysis, in addition the metabolic feature of these oils are considered having juvenilizing action, this led to some morphogenetic abnormalities in treated larvae. Similar outcomes were obtained by Sharaby, A. and A. El-Nojiban [29]. However, more information is needed before these sublethal effects can be fully explained and understood in Integrated Pest Management (IPM) programs using these plant extracts.

Table 2. Effects of peppermint oil nano-formulations on certain biological aspects of the $2^{\text {nd }}$ instar larvae of A. ipsilon.

\begin{tabular}{|c|c|c|c|c|c|}
\hline $\begin{array}{ll}\text { Parameter } & \text { Formulation } \\
\end{array}$ & Bulk oil & Nano-emulsion & $\begin{array}{l}\text { Loaded nano- } \\
\text { emulsion }\end{array}$ & Control & Mean/F \\
\hline Larval duration (days) & $30.41 \pm 0.61^{\mathrm{b}}$ & $31.55 \pm 1.11^{\mathrm{b}}$ & $36.36 \pm 0.47^{\mathrm{a}}$ & $18.84 \pm 0.10^{\mathrm{c}}$ & $146.59 * *$ \\
\hline \%Larval mort. (*) & $\begin{array}{l}17.50 \\
\left(25.10 \pm 0.40^{c}\right)\end{array}$ & $\begin{array}{l}32.50 \\
\left(35.07 \pm 0.38^{b}\right)\end{array}$ & $\begin{array}{l}50.00 \\
\left(45.00 \pm 0.35^{\mathrm{a}}\right)\end{array}$ & $\begin{array}{l}5 \\
\left(12.87 \pm 0.78^{\mathrm{d}}\right)\end{array}$ & $732.74 * *$ \\
\hline$\%$ Malformations in larvae $(*)$ & $\begin{array}{l}5.88 \\
14.13 \pm 0.69^{\mathrm{a}, \mathrm{b}}\end{array}$ & $\begin{array}{l}11.11 \\
19.37 \pm 0.55^{\mathrm{a}}\end{array}$ & $\begin{array}{l}18 \\
25.30 \pm 6.41^{\mathrm{a}}\end{array}$ & $1.90 \pm 0.05^{\mathrm{c}}$ & $8.73 * *$ \\
\hline Pupal duration (Days) & $13.00 \pm 0.55^{\mathrm{a}}$ & $14.00 \pm 0.37^{\mathrm{a}}$ & $14.00 \pm 0.45^{\mathrm{a}}$ & $11.00 \pm 0.45^{\mathrm{b}}$ & $9.74 * *$ \\
\hline \% Pupal mortality $(*)$ & $\begin{array}{l}56.52 \\
\left(49.03 \pm 0.32^{b}\right)\end{array}$ & $\begin{array}{l}57.89 \\
49.60 \pm 0.35^{\mathrm{b}}\end{array}$ & $\begin{array}{l}100.00 \\
88.10 \pm 1.90^{\mathrm{a}}\end{array}$ & $\begin{array}{l}7.80 \\
\left(16.40 \pm 0.64^{\mathrm{c}}\right)\end{array}$ & $812.36^{* *}$ \\
\hline$\%$ Malformations in pupa $(*)$ & $18.07 \pm 0.86^{\mathrm{b}, \mathrm{c}}$ & $31.33 \pm 0.36^{\mathrm{a}, \mathrm{b}}$ & $34.93 \pm 5.38^{\mathrm{a}}$ & $4.60 \pm 2.40^{c}$ & $21.40 * *$ \\
\hline Adult longevity (days) & $6.20 \pm 0.37^{\mathrm{a}, \mathrm{b}}$ & $5.00 \pm 0.32^{\mathrm{b}}$ & - & $7.50 \pm 0.65^{\mathrm{a}}$ & $5.12 *$ \\
\hline Fecundity & $595.75 \pm 128.54^{\mathrm{a}, \mathrm{b}}$ & $488.75 \pm 120.63^{b}$ & - & $1081.60 \pm 151.04^{\mathrm{a}}$ & $5.54^{*}$ \\
\hline$\%$ Hatchability $(*)$ & $\begin{array}{l}78 \\
62.00 \pm 0.40^{\mathrm{b}}\end{array}$ & $\begin{array}{l}35 \\
36.30 \pm 0.35^{\mathrm{c}}\end{array}$ & - & $\begin{array}{l}94 \\
75.89 \pm 0.71^{\mathrm{a}}\end{array}$ & $1531 * *$ \\
\hline
\end{tabular}

(*) Arcsin transformation of percentage. NS= Not significant. * Significant. **Highly significant. Each value represent the means of four replicates (each composed of 10 larvae) \pm s.e.. Values with different letters within the same row are significantly different (P. $<0.05)($ ANOVA) (Tukey test).

\subsection{Effect of Bulk and Nano-formulations of Neem and Pepper Mint Oils on Certain Enzymatic Activities of $2^{\text {nd }}$ and $4^{\text {th }}$ Instar Larvae of Agrotis Ipsilon}

The biochemical effects of nano-formulations compared to the bulk oil of both neem and peppermint were tested against $2^{\text {nd }}$ and $4^{\text {th }}$ instar larvae of $A$. ipsilon. The tested larvae were treated by the calculated $\mathrm{LC}_{50}$ values of each formulation. Enzymatic activities were recorded after 96 hours post treatment.

\subsubsection{Effect on the $2^{\text {nd }}$ Instar Larvae}

The activity of $\alpha$ - amylase, invertase, trehalase and protease enzymes in larvae treated with nano-formulas of either neem or peppermint oils show significant inhibition when compared with control larvae which recorded $6.18 \mu \mathrm{g}$ glucose $/ \mathrm{min} / \mathrm{mg}$ protein. Data in Table 3 show the maximum decrease values of amylase enzyme activity was for bulk neem oil which was0.75 $\mu \mathrm{g} \quad(-87.86 \%)$ compared with5.08 $\mu \mathrm{g}(-17.80)$ for peppermint bulk oil. The same trend was followed out for the activity of invertase, trehalase and protease enzymes. Also, reduction in the specific activity of invertase enzyme was observed. The maximum suppression of gut enzyme activity was obtained from loaded formulation from neem nano-emulsion which was reduced to 11.84 ($82.37 \%$ ) $\mu \mathrm{g}$ glucose / $\mathrm{min} / \mathrm{mg}$ protein compared with control value of $67.17 \mu \mathrm{g}$ glucose $/ \mathrm{min} / \mathrm{mg}$ protein. The activity of trehalase was also significantly reduced to reach
$37.06(-46.71 \%) \mu \mathrm{g}$ glucose $/ \mathrm{min} / \mathrm{mg}$ protein neem nanoemulsion. Results in Table 3 show that protease activity in the $2^{\text {nd }}$ instar larvae seemed to be affected to some extent by all tested compounds.

The foregoing results are in agreement with those obtained by Rao, P. J. [33] who pointed out that botanical oils have great effect on digestive enzymes and decrease the haemolymph protein. Rharrabe et al. [34] suggested that the reductions of digestive enzymes may be due to the plant secondary metabolites that inhibit the activity of these enzymes and cause cytotoxicity in the epithelial cells that synthesize these digestive enzymes. Also, Hill and Orchard [35] referred the reduction of enzymatic activities by the lack of food intake.

The activity of alkaline phosphotase show different responses between increasing and decreasing with the different treatments. The $2^{\text {nd }}$ instar larvae show decreasing to-74.85 and-39.00 by treatments of neem bulk and nanoemulsions respectively. There was increasing in the enzyme activity with the remained treatments to reach +41.80 by peppermint loaded nano-emulsion. The obtained data may be attributed to the effect of the tested formulation on the phosphorylation reaction as indicated by Etebari et al. [36] who showed that ALP is involved in the trans phosphorylation reaction.

In case of $2^{\text {nd }}$ instar larvae, all tested formulations exhibited a significant increase in phenoloxidase. The same finding was reported by Farrag, A. A. [37] who showed the 
same increase in phenoloxidase parameters when they treated $S$. littoralis larvae with neem oil after 2 days and they indicated that the insect immune response increase and attack these foreign particles. Also, the present results are in parallel with Santoyo, I. G. and Aguilar, A. C. [38] who stated that in invertebrate immunology have documented a complex array of host defenses. Gilmour [39, 40] suggested the function of phenol peroxidase in hardening and darkening of the insect cuticle.

In case of chitinase, the $2^{\text {nd }}$ instar larvae showed a significant increase in enzyme activity when compared with the control value (22.27 $\mu \mathrm{g} \mathrm{NAGA} / \mathrm{min} / \mathrm{mg}$ protein) when treated with neem loaded nano-emulsion, peppermint loaded nano emulsion and bulk pepper mint (Table 3), but there were significant decrease when treated with the other formulations.

Total protein was affected by treatment of different formulations. It was increased to be $484.93(+32.22 \%)$, $509.43(+38.90 \%), 479.67(+30.78 \%), 575.08(+56.80 \%)$ and $643.36(+75.42 \%)$ for bulk mint and pepper mint loaded nano-emulsion, respectively. While there was decreasing of total protein level to be $351.00(-4.30 \%)$ recorded by the treatment of peppermint nano-emulsion.

Table 3. Specific activities of certain enzymes of $2^{\text {nd }}$ instar larvae of A. ipsilon treated with prepared formulation.

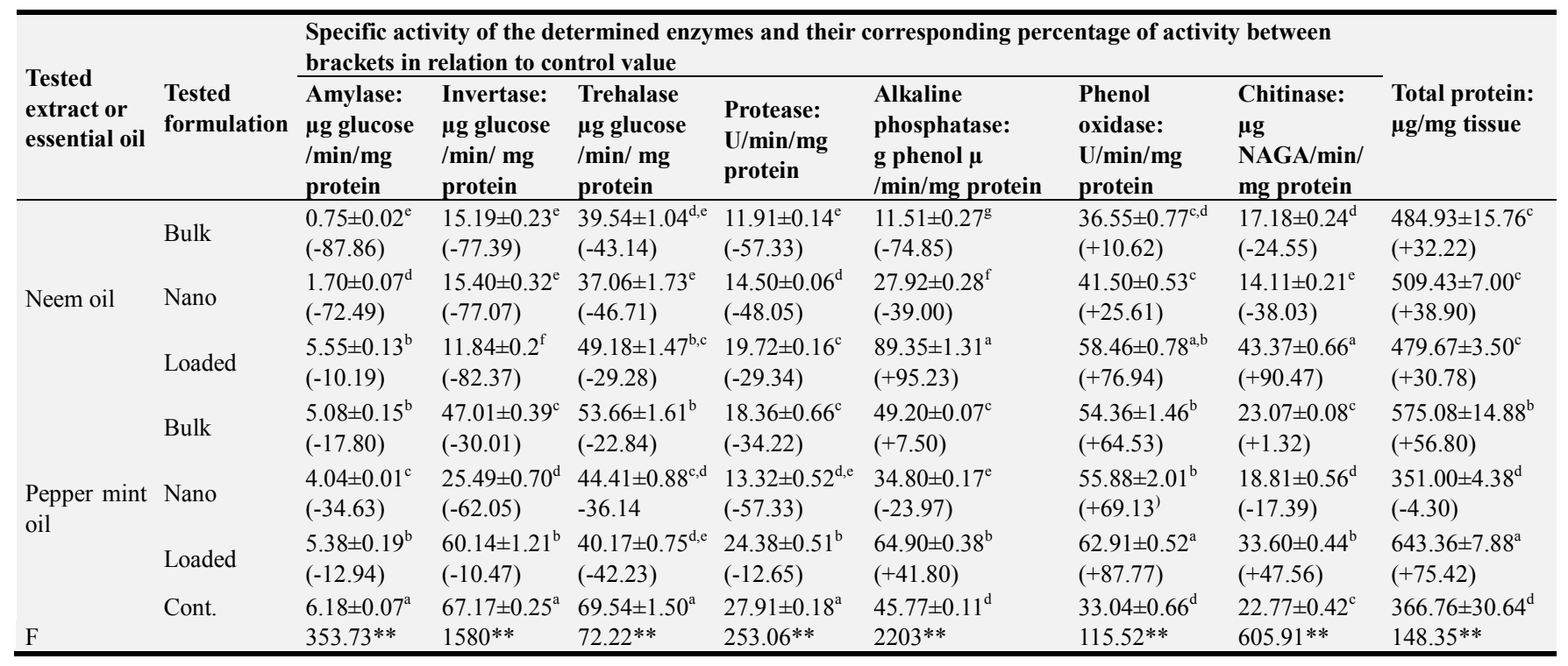

*Each value of the specific activity represents the mean of 3 replicates \pm SE Values between brackets represent the percentage of increase or decrease compared to the control larvae. Values with different letters within the same column are significantly different (p. $<0.05)($ Tukey test).

\subsubsection{Effect on the $4^{\text {th }}$ Instars Larvae of A. ipsilon}

The $4^{\text {th }}$ instars larvae of $A$. ipsilon were treated with all tested formulations and the results of biochemical effects of nano-formulations followed the same trend of the $2^{\text {nd }}$ instar larvae. Table 4 show that Peppermint nano-emulsion was the most effective component. It significantly reduced the enzymatic activity of the three digestive enzymes as they reached -93.58, -97.73 and-85.46 for $\alpha$ - amylase, invertase and trehalase respectively when compared with the control.

Protease enzyme activity was inhibited by all treatments in comparison to control larvae $(27.91 \mathrm{U} / \mathrm{min} / \mathrm{mg}$ protein). Data arranged in a descending order according to the enzymatic activity as follows: $24.89(-10.82 \%), 19.72(-29.34 \%), 18.92$ $(-32.21 \%), 14.50(-48.05 \%), 13.76(-50.70 \%)$ and $11.82(-$ $57.65 \%$ ) for peppermint loaded nano-emulsion, neem loaded nano-emulsion, bulk peppermint, neem nano-emulsion, peppermint nano-emulsion and bulk neem, respectively.

Alkaline phosphatase showed decreasing in its activity with all treatments Table 4 . They have been recorded as follows: $151.21(-13.60 \%), 101.82)(-41.82 \%), 64.79$ ($62.98 \%), 48.16(-72.48 \%), 41.93(-76.04 \%)$ and 23.15 ($86.77 \%$ ) for peppermint loaded nano-emulsion, bulk pepper mint, neem nano-emulsion, bulk neem, neem loaded nanoemulsion and bulk peppermint, respectively. The control larvae reported as $175.02 \mu \mathrm{g}$ phenol $/ \mathrm{min} / \mathrm{mg}$ protein. The obtained data may be attributed to the effect of the tested formulation on the phosphorylation reaction as indicated by Etebari, K. [36] who stated that ALP is involved in the Trans phosphorylation reaction. The present results are in agreement with Osman, H. H. [41] who clearly indicated that the alkaline phosphatases activities were highly significantly reduced at all- time interval post-treatment of Spodoptera littoralis larvae treated with nano-zinc oxide.

Phenol oxidase enzyme showed increasing in its activity after exposing to all treatments (Table 4). The control larvae reported as $63.53 \mathrm{U} / \mathrm{min} / \mathrm{mg}$ proteins. The treatment data can be arranged in a descending order according the enzyme activity as follows: $115.09(+81.16 \%), 112.53(+77.13 \%)$, $105.14(+65.50 \%), 104.43(+64.38 \%), 96.58(+52.02 \%)$ and $87.66(+37.98 \%)$ for pepper mint loaded nano-emulsion, bulk pepper mint, neem nano-emulsion, pepper mint nanoemulsion, neem loaded nano-emulsion and bulk neem, respectively. These findings are in consistence with Farrag, A. A. [37] who recorded the same increase in phenol oxidase parameters when treated $S$. littoralis larvae with neem oil 
after 2 days and they indicated that the insect immune response increase and attack these foreign particles.

Chitinase enzyme activity significantly decreased after all treatments when compared to the control larvae $(80.13 \mu \mathrm{g}$ $\mathrm{NAGA} / \mathrm{min} / \mathrm{mg}$ protein). The required data in Table 4 can be arranged in a descending order according to the enzyme activity as follows: $65.32(-18.48 \%), 64.33(-19.72 \%), 38.95$ (-51.39\%), 28.37 (-64.60\%), $21.57(-73.08 \%)$ and $21.13(-$ $73.63 \%)$ for peppermint loaded nano-emulsion, bulk peppermint, neem nano-emulsion, neem loaded nanoemulsion, bulk neem and peppermint nano-emulsion, respectively. Retnakaran and Grant [42] reported that chitin synthesis in insects begins by the formation of oligosaccharides synthesized in the epidermal cell, transport to the cuticle and polymerize to form discrete chitin microfibrils and are covalently bound to proteins. Structural integrity is essential for the polymerization of the oligosaccharides, the second polymerization step is the inhibition site. They added that inhibition to the enzyme that catalyzing the polymerization of UDP-N -acetyl glucosamine to chitin or inhibition to the transport of UDP$\mathrm{N}$ - acetyl glucosamine across bio membranes, inhibition to protease that activates the chitin syntheses zymogen and inhibits ecdysone metabolizing enzymes resulting in accumulation of ecdysone.. This simulates chitinase production which results in molting disruption. This inhibition of chitinase activity can be explained by the properties of the botanical oils as a growth regulator were originally inappropriately timed and poorly coordinated moulting processes, the resulting perturbation of moulting and metamorphosis lead to death, usually because the insects cannot escape from the exuvie [43].

Total protein was affected by treatment of different formulations. It was decreased to be 532.19 (-6.08\%), 271.35 (-25.11\%), 409.65 (-27.70\%), 398.27 (-29.71\%), 386.89 ($31.72 \%)$ and $154.06(-72.81 \%)$ for bulk neem, neemnanoemulsion, neem loaded nano-emulsion, bulk pepper mint, peppermint nano-emulsion and peppermint loaded nanoemulsion, respectively.

Table 4. Specific activities of certain enzymes of $4^{\text {th }}$ instar larvae of A. ipsilon treated with prepared Formulations.

\begin{tabular}{|c|c|c|c|c|c|c|c|c|c|}
\hline \multirow{2}{*}{$\begin{array}{l}\text { Tested } \\
\text { extract } \\
\text { or } \\
\text { essential } \\
\text { oil }\end{array}$} & \multirow[b]{2}{*}{$\begin{array}{l}\text { Tested } \\
\text { formulation }\end{array}$} & \multicolumn{7}{|c|}{$\begin{array}{l}\text { Specific activity of the determined enzymes and their corresponding percentage of activity between } \\
\text { brackets in relation to control value }\end{array}$} & \multirow[b]{2}{*}{$\begin{array}{l}\text { Total protein: } \\
\mu \mathrm{g} / \mathrm{mg} \text { tissue }\end{array}$} \\
\hline & & $\begin{array}{l}\text { Amylase: } \mu \mathrm{g} \\
\text { glucose } \\
/ \mathrm{min} / \mathrm{mg} \\
\text { protein }\end{array}$ & $\begin{array}{l}\text { Invertase } \\
\mu \mathrm{g} \text { glucose } \\
/ \mathrm{min} / \mathrm{mg} \\
\text { protein }\end{array}$ & $\begin{array}{l}\text { Trehalase } \\
\mu \mathrm{g} \text { glucose } \\
/ \mathrm{min} / \mathrm{mg} \\
\text { protein }\end{array}$ & $\begin{array}{l}\text { Protease: } \\
\text { U/min/mg } \\
\text { protein }\end{array}$ & $\begin{array}{l}\text { Alkaline } \\
\text { phosphatase: } \\
\text { g phenol } \mu \\
\text { /min/mgprotein }\end{array}$ & $\begin{array}{l}\text { Phenol } \\
\text { oxidase } \\
\text { U/min/mg } \\
\text { protein }\end{array}$ & $\begin{array}{l}\text { Chitinase: } \\
\mu \mathrm{g} \\
\text { NAGA/min/ } \\
\text { mg protein }\end{array}$ & \\
\hline \multirow{3}{*}{$\begin{array}{l}\text { Neem } \\
\text { oil }\end{array}$} & Bulk & $\begin{array}{r}3.66 \pm 0.13^{\mathrm{d}} \\
(-84.55)\end{array}$ & $\begin{array}{c}97.24 \pm 2.21^{\mathrm{b}, \mathrm{c}} \\
(-84.73)\end{array}$ & $\begin{array}{c}111.29 \pm 4.45^{\mathrm{c}} \\
(-64.86)\end{array}$ & $\begin{array}{r}11.82 \pm .14^{\mathrm{e}} \\
(-57.65)\end{array}$ & $\begin{array}{c}48.16 \pm 0.74^{\mathrm{e}} \\
(-72.48)\end{array}$ & $\begin{array}{c}87.66 \pm 0.63^{\mathrm{d}} \\
(+37.98)\end{array}$ & $\begin{array}{c}21.57 \pm 0.23^{\mathrm{e}} \\
\quad(-73.08)\end{array}$ & $\begin{array}{c}532.19 \pm 36.76^{\mathrm{a}} \\
(-6.08)\end{array}$ \\
\hline & Nano & $\begin{array}{r}3.71 \pm 0.24^{\mathrm{d}} \\
(-84.34)\end{array}$ & $\begin{array}{c}74.79 \pm 1.79^{c} \\
(-88.26)\end{array}$ & $\begin{array}{c}75.03 \pm 1.65^{\mathrm{d}} \\
(-76.30)\end{array}$ & $\begin{array}{r}14.50 \pm .06^{\mathrm{d}} \\
(-48.05)\end{array}$ & $\begin{array}{c}64.79 \pm 0.37^{\mathrm{d}} \\
(-62.98)\end{array}$ & $\begin{array}{c}105.14 \pm 0.88^{\mathrm{b}} \\
(+65.50)\end{array}$ & $\begin{array}{c}38.95 \pm 0.85^{\mathrm{c}} \\
(-51.39)\end{array}$ & $\begin{array}{c}271.35 \pm 22.76^{\mathrm{c}} \\
(-25.11)\end{array}$ \\
\hline & Loaded & $\begin{array}{r}2.88 \pm 0.01^{\mathrm{d}} \\
(-87.84)\end{array}$ & $\begin{array}{l}16.24 \pm 0.31^{\mathrm{d}} \\
(-97.45)\end{array}$ & $\begin{array}{l}92.39 \pm 4.11^{\mathrm{c}, \mathrm{d}} \\
(-70.82)\end{array}$ & $\begin{array}{l}19.72 \pm 0.16^{c} \\
(-29.34)\end{array}$ & $\begin{array}{l}41.93 \pm 1.02^{\mathrm{f}} \\
\quad(-76.04)\end{array}$ & $\begin{array}{r}96.58 \pm 0.51^{\mathrm{c}} \\
\quad(+52.02)\end{array}$ & $\begin{array}{c}28.37 \pm 0.75^{\mathrm{d}} \\
\quad(-64.60)\end{array}$ & $\begin{array}{c}409.65 \pm 17.51^{b} \\
(-27.70)\end{array}$ \\
\hline \multirow{4}{*}{$\begin{array}{l}\text { Pepper } \\
\text { mint oil }\end{array}$} & Bulk & $\begin{array}{r}6.62 \pm 0.16^{\mathrm{c}} \\
(-72.06)\end{array}$ & $\begin{array}{c}107.33 \pm 2.66^{\mathrm{b}} \\
\quad(-83.15)\end{array}$ & $\begin{array}{c}134.68 \pm 4.15^{b} \\
(-57.46)\end{array}$ & $\begin{array}{c}18.92 \pm 0.33^{\mathrm{c}} \\
(-32.21)\end{array}$ & $\begin{array}{c}101.82 \pm 0.74^{\mathrm{c}} \\
(-41.82)\end{array}$ & $\begin{array}{c}112.53 \pm 0.41^{\mathrm{a}} \\
\quad(+77.13)\end{array}$ & $\begin{array}{c}64.33 \pm 1.91^{\mathrm{b}} \\
(-19.72)\end{array}$ & $\begin{array}{c}398.27 \pm 21.89^{b} \\
(-29.71)\end{array}$ \\
\hline & Nano & $\begin{array}{r}1.52 \pm 0.10^{\mathrm{e}} \\
(-93.58)\end{array}$ & $\begin{array}{c}14.43 \pm 0.14^{\mathrm{d}} \\
(-97.73)\end{array}$ & $\begin{array}{c}46.05 \pm 0.94^{\mathrm{e}} \\
(-85.46)\end{array}$ & $\begin{array}{c}13.76 \pm 0.25^{\mathrm{d}} \\
(-50.70)\end{array}$ & $\begin{array}{c}23.15 \pm 0.60^{g} \\
(-86.77)\end{array}$ & $\begin{array}{c}104.43 \pm 1.10^{\mathrm{b}} \\
(+64.38)\end{array}$ & $\begin{array}{c}21.13 \pm 0.61^{\mathrm{e}} \\
(-73.63)\end{array}$ & $\begin{array}{c}386.89 \pm 26.26^{\mathrm{b}} \\
(-31.72)\end{array}$ \\
\hline & Loaded & $\begin{array}{r}8.17 \pm 0.05^{\mathrm{b}} \\
(-65.51)\end{array}$ & $\begin{array}{c}94.83 \pm 3.54^{\mathrm{b}, \mathrm{c}} \\
\quad(-85.11)\end{array}$ & $\begin{array}{c}106.67 \pm 3.33^{\mathrm{c}} \\
(-66.31)\end{array}$ & $\begin{array}{c}24.89 \pm 0.59^{b} \\
(-10.82)\end{array}$ & $\begin{array}{c}151.21 \pm 1.96^{\mathrm{b}} \\
(-13.60)\end{array}$ & $\begin{array}{c}115.09 \pm 0.61^{\mathrm{a}} \\
(+81.16)\end{array}$ & $\begin{array}{c}65.32 \pm 0.19^{b} \\
(-18.48)\end{array}$ & $\begin{array}{c}154.06 \pm 7.01^{\mathrm{d}} \\
(-72.81)\end{array}$ \\
\hline & Cont. & $23.69 \pm 0.40^{\mathrm{a}}$ & $637.01 \pm 14.88^{\mathrm{a}}$ & $316.63 \pm 8.09^{\mathrm{a}}$ & $27.91 \pm 0.18^{a}$ & $175.02 \pm 1.16^{\mathrm{a}}$ & $63.53 \pm 0.61^{\mathrm{e}}$ & $80.13 \pm 0.99^{a}$ & $566.62 \pm 73.29^{\mathrm{a}}$ \\
\hline $\mathrm{F}$ & & $1500.00 * *$ & $1342.00 * *$ & $402.22 * *$ & $416.73 * *$ & $3002.00 * *$ & $618.127 * *$ & $630.03 * *$ & $48.57 * *$ \\
\hline
\end{tabular}

*Each value of the specific activity represents the mean of 3 replicates \pm SE. Values between brackets represent the percentage of increase or decrease compared to the control larvae. Values with different letters within the same column are significantly different (p. $<0.05)$ (Tukey test).

Abdel-Hakim et al. [44] found that feeding of $4^{\text {th }}$ larval instar of of $A S$. A.ipsilon on Neem Azal T/S had reduced the total protein and lipid content. In contrast $A$. ipsilon $2^{\text {nd }}$ instar treated larvae showed increase of total protein levels. These results were parallel to those found by Abd El-Aziz, M. F. [45] who reported that larvae treated with eucalyptus, citronella, geranium and marjoram essential oils increased total protein of last larval instar, females and males of the Phthorimaea operculella (Zeller). The increase in the total protein with different oils treatments may be attributed to the increase in protein biosynthesis by tool of amino acid and may be a kind of detoxification mechanism [46].

\section{Conclusion}

Botanical insecticides and essential oils can contribute to reduce the pest population and increase food production. They are safe and eco-friendly. The biological effects of the botanical oils on insect pests may attribute to their effect on insect neuro endocrine system and juvenile hormone leading to hormone unbalance occurring malformation and decreasing moths fecundity and egg fertility to decreasing in periods and time of adults mating which lead to decreasing of ovulation. Also, they have great effect on digestive enzymes and cause cytotoxicity in epithelial cells that synthesize these digestive enzymes. The use of nano- emulsions as carriers of pesticides decrease the use of organic solvents and increase the dispersity, wettability and penetration properties of the droplets may lead to improvement of the biological efficacy of pesticides. 


\section{Acknowledgements}

The authors appreciate the role of the National Research Centre in the financial support offered for this investigation

\section{References}

[1] Muhammad, S.; U. Farman; N. Muhammad; A. Muhammad; A. U. R. Saljoqi and Z. Muhammad (2007) Effect of various insecticides for the control of Potato cutworm (Agrotis ipsilon Huf., Noctuidae: lepidoptera) at kalam swat. Sahad J. Agric., 23 (2): 423-426.

[2] Watson, R. N. (2016) Control of greasy cutworm (Lepidoptera: Noctuidae) in seedling maize. New Zealand J. Exp. Agric., 9 (3-4): 351-356.

[3] Busching, M. K. and F. T. Turpin (1977) Survival and development of black cutworm (Agrotis ipsilon) larvae on various species of crop plants and weeds. Environ. Entomol, 6: $63-65$.

[4] EI-Salamouny S., Lange M., Jutzi M., Huber J., Jehle J. A. (2003) Comparative study on the susceptibility of cutworms (Lepidoptera: Noctuidae) to Agrotis segetum nucleopolyhedrovirus and Agrotis ipsilon nucleo polyhedrovirus. J. Invert. Pathol. 84: 75-82. doi: 10.1016/j.jip.2003.08.005.

[5] Amoabeng, B. W.; G. M. Gurr; C. W. Gitau; H. I. Nicol; L. Munyakazi and P. C. Stevenson (2013) Tri-Trophic Insecticidal Effects of African Plants against Cabbage Pests. Plos one, 8 (10): 1371-1382.

[6] Dimetry, N. Z. (2012). Prospects of botanical pesticides for the future in integrated pest management program (IPM) with special reference to neem uses in Egypt. Arch. Phytopathol. Plant Protec., 45: 1138-1161.

[7] Dimetry, N. Z.; A. Y. El-Laithy; A. M. E. Abd El-salam and A. E. El-Saiedy (2013) Management of the major piercing sucking pests infesting cucumber under plastic house conditions. Arch. Phytopathol. Plant Protec.; 46: 158-171.

[8] Mubayi, A.; S. Chatterji; P. M. Rai and G. Watal (2012) Evidence based green synthesis of nanoparticles. Adv. Materials Methods., 3 (6): 519-525.

[9] Raveendran, P.; J. Fu and S. L. Wallen (2006) A simple and "green" method for the synthesis of $\mathrm{Au}, \mathrm{Ag}$, and Au-Ag alloy nanoparticles. Green Chem., 8: 34-38.

[10] Ghormade, V.; V. D. Mukund and M. P. Kishore (2011) Perspectives for nano-biotechnology enabled protection and nutrition of plants. Biotech. Adv., 29: 792-803.

[11] Anjali, C. H.; S. S. Khan; K. Margulis-Goshen; S. Magdassi; A. Mukherjee and N. Chandrasekaran (2010) Formulation of water-dispersible nanopermethrin for larvicidal applications. Ecotox. Environ. Safe., 73: 1932-1936.

[12] Anjali, C. H.; Y. Sharma; A. Mukherjee and N. Chandrasekaran (2012) Neem oil (Azadirachta indica) nanoemulsion a patent larvicidal agent against Culex quinquefasciatus. Pest. Manag. Sci, 68 (2): 158-63.

[13] Dimetry, Nadia Z.; Amin, A. H.; Bayoumi, A. E.. AbdelRaheem, M. A. and Youssef, Dalia A. (2019) Comparative Toxicity between Neem and Pepper Mint Oils Nano
Formulations against Agrotis ipsilon (Hufn.) larvae (Lepidoptera: Noctuidae). J. Botanic. Res., 01, Issue 01, April 2019: 13-19.

[14] Frederiksen, H. K.; H. G. Kristensen and M. Pedersen (2003) Solid lipid microparticle formulations of the pyrethroid gamma-cyhalothrin-incompatibility of the lipid and the pyrethroid and biological properties of the formulations. J. Control. Release., 86: 243-252.

[15] Guenther, E. (1961) The essential oils. Vol (4) Von Nostan and con. N. York. pp. 132-147.

[16] Azhari Siddeeg, Zakaria A. Salih, Rabab M. E. Mukhtar \& Ali O. Ali (2018) Extraction and Characterizati 1on of Peppermint (Mentha piperita) Essential Oil and its Assessment as Antioxidant and Antibacterial. Gezira Journal of Engineering and Applied Sciences vol 13 (1): 1-15, 2018.

[17] Yousef, Dalia A.; Bayoum, A. E.; Dimetry, N. Z.; Amin, A. H. and Hoballah, E. M. (2018) Evaluating Effect of Peppermint Oil (Mentha pipreta) and its Nano-Formulations on Some Enzmatic Activities and Bionomics of Cotton Leaf Worm Spodoptera littoralis.

[18] Lertsutthiwong, P.; K. Noomun; N. Jongaroonngamsang; P. Rojsitthisak U. and Nimmannit (2008) Preparation of alginate nanocapsules containing turmeric oil. Carbohydr. Polym., 74: 209-214.

[19] Ishaaya, I. and Swirski, E. (1976) Trehalase, invertase and amylase activities in the black scale Saissetia oleae, and their relation to host adaptability. J. Insect Physiol., 22: 1025-1029.

[20] Ascher, K. R. and Ishaaya, S. (2004). Antifeedant and protease and amylase inhibiting activity of fentin acetate in Spodoptera littoralis larvae. Pest. Biochem. Physiol., 3 (3): 326-336.

[21] Ishaaya, I.; I. Moore and I. Joseph (1971) Protease and amylase activity in larvae on the Egyptian cotton worm, Spodoptera littoralis. J. Insect Physiol., 17: 45-95.

[22] Powell, M. E. A. and M. J. H. Smith (1954) The determination of serum acid and alkaline phosphatases activity with 4-amino antipyrine. J. Clin. Pathol., 7: 245- 248.

[23] Ishaaya, I. and J. E. Casida (1974) Dietary TH 6040 alters composition and enzyme activity of housefly larval cuticle. Pestic. Biochem. Physiol., 4: 484-490.

[24] Bradford, M. M. (1976) A rapid and sensitive method for the quantitative of microgram quantities of protein utilizing the principle of protein-dye binding. Anal. Biochem., 72: 248-254.

[25] Rao, B. R.; P. Rajasekhar; M. Venkataiah and N. V. Rao (1995) Bio-efficacy of 'Neem Azal' (azadirachtin 10,000 ppm) against cotton bollworm, Helicoverpa armigera (Hübner). J. Entomol. Res., 19 (4): 329-333.

[26] Ma, X.; Lee, J. G.; Y. Dengand A. Kolmakov (2010) Interactions between engineered nanoparticles (ENPs) and plants: Phytotoxicity, uptake and accumulation. Sci. of the Total Environ., 408: 3053-3061.

[27] Pineda, S.; A. M. M1artinez; J. I. Ficueroa; M. I. Schneider; P. D. Estal; E. Vinuela; B. Gomez; G. Smagghe and F. Budia (2009) Influence of azadirachtin and methyl oxyfenozide on life parameters of $S$. littoralis (Lepidoptera: Noctuidae). J. Econ. Entomol., 102 (4): 1490-1496. 
[28] Mohamed, Samar, S. I. (2016) Applications of some biotechnological methods for controlling the most important pests of potatoes. Ph.D. Thesis. Fac. Science for Girls. AlAzhar University. 306 pp.

[29] Sharaby, A. and A. El-Nojiban (2015) Evaluation of some plant essential oils against the black cutworm Agrotis ipsilon. Global J. Adv. Res., 2 (4): 701-711.

[30] Huang, Z.; P. Shi; J. Dai and J. Du (2004) Protein metabolism in Spodoptera litura (F.) is influenced by the botanical insecticides azadirachtin. Pest biochem. Physiol., 80 (2): 8593.

[31] Isman, M. B.; S. Miresmailli and C. Machial (2011) Commercial opportunities for pesticides based on plant essential oils in agriculture, industry and consumers products. Phytochem. Rev., 10: 197-204.

[32] Gutierrez, L.; A. Escudero; R. Battle and C. Nerin (2009) The effect of mixed antimicrobial agents and flavors in active packaging films. J. Agric. Food Chem., 57: 8564-8571.

[33] Rao, P. J.; K. H. Kumar; S. Sing and B. Sibrhmanyam (1999) Effect of Artemisia annua oil on development and reproduction of Dysdecus koenigii F. Division Ent. India. J. Appl. Ent., 123: 315-318.

[34] Rharrabe, K.; N. Bouayad and F. Saah (2009) Effect of ingested 20-hydroxycdysone on development and midgut epithelial cells of Plodia interpunctella (Lepidoptera, Pyralidae). Pestic. Biochem. Physiol., 93: 112-119.

[35] Hill, S. R. and I. Orchard (2005) In vitro analysis of the digestive enzymes amylase and $\alpha$-glucosidase in the midgets of Locusta migratoria L. in response to the myosppressin, J. Insect Physio., 51: 1-9.

[36] Etebari, K.; S. Z. Mirhoseini and L. Matindoost (2005) A study on intraspecific biodiversity of eight groups of silk.; Mirhoseini worm (Bombyx mori) by biochemical markers. Insect. Sci., 12: 87-94.

[37] Farrag, A. A.; T. A. Abd-Elfattah; G. M. Abdelatef and M. K. El-Dydamony (2015) Effect of four bioactive compounds separately and in combination with enzymes of Schistocerca gregaria. Plant Prot. J. Path., 6: 871-883.

[38] Santoyo, I. G. and Aguilar, A. C. (2012) Phenol oxidase: a key component of the insect immune system. Entomol. Exp. Applicata, 142 (1): 1-16.

[39] Gilmour, D. (1961) The biochemistry of insects. Academic press, New York and London.

[40] Senthil-Nathan, Sengottayan (2013) Physiological and biochemical effect of neem and other Meliaceae plants secondary metabolites against Lepidopteran insects. Front. Physiol. 4: 359, 20 December 2013. https://doi.org/10.3389/fphys.2013.co359.

[41] Osman, H. H.; H. F. Abdel-Hafez and A. A. Khidr (2015) Comparison between the Efficacy of Two Nano-Particles and Effective Microorganisms on Some Biological and Biochemical Aspects of Spodoptera littoralis. J. Agr. Innov. Res., 3 (6): 2319-1473.

[42] Retnakaran, A. and G. G. Grant (1985) Control of the oak-leaf shredder, Croesia semi purpurana (Kearfott) (Lepidoptera: Tortricidae), by aerial application of diflubenzuron. Can. J. Ent., 117: 363-369.

[43] Liburd, E. O.; J. E. Funderburk and S. M. Olson (2000) Effect of biological and chemical insecticides on Spodoptera species (Lep. Noctuidae) and marketable yield of tomatoes. J. App. Entomol., 124: 19-25.

[44] Abdel-Hakim, E.; N. Y. Salem; E. Sammour and S. S. Ibrahim (2011) Influence of three plant extracts on some biological and biochemical aspects of the black cutworm Agrotis ipsilon (Hufn.) Bull. NRC, 36 (3): 223-237.

[45] 41-Abd El-Aziz, M. F. (2011) Bioactivities and biochemical effects of marjoram essential oil used against potato tuber moth Phthorimaea operculella Zeller (Lepidoptera: Gelechiidae). Life Science J., 8 (1): 288-297.

[46] Shoukry, I. F.; A. F. A. Khalaf; A. Fattah and and K. S. Khater (2003) Toxicological evaluation of some botanical oils on biochemical aspects in the Indian meal moth Plodia interpunctella $(\mathrm{Hb}$.) (Lepidoptera: Pyralidae). Egypt. J. Biol., 5: $155-163$. 